\title{
BIODEGRADASI LIMBAH KULIT BUAH KAKAO (Theobroma cacao L.) OLEH KAPANG Aspergillus niger DENGAN VARIASI JUMLAH INOKULUM DAN WAKTU INKUBASI
}

\section{BIODEGRADATION OF CACAO (Theobroma cacao L.) RIND WASTE BY Aspergillus niger WITH VARIATION OF INOCULUM CONCENTRATION AND INCUBATION TIME}

\author{
Alfian Siswanto, Ida Bagus Gede Darmayasa, I Ketut Muksin \\ Program Studi Biologi, Fakultas MIPA, Universitas Udayana \\ Email: agustinusalfian29@gmail.com
}

\begin{abstract}
ABSTRAK
Limbah hasil panen dari pengolahan buah kakao (Theobroma cacao L.) yang tidak ditangani dengan baik dapat mencemari lingkungan sekitar perkebunan. Pemanfaatan limbah kulit buah kakao yang paling sederhana adalah sebagai kompos, namun jika tanpa perlakuan khusus akan menjadi kurang efektif karena kandungan hara limbah kulit buah kakao dalam keadaan segar masih sangat komplek serta $\mathrm{C} / \mathrm{N}$ rasio yang dimilikinya masih tinggi. Tujuan penelitian ini adalah untuk mengetahui kemampuan kapang Aspergillus niger dalam mendegradasi selulosa pada limbah kulit buah kakao yang diindikasikan dari nilai $\mathrm{C} / \mathrm{N}$ rasio, dengan kombinasi jumlah inokulum dan waktu inkubasi. Metode yang dilakukan yaitu diawali dengan isolasi dan identifikasi kapang A.niger dari serasah perkebunan kakao, kemudian dilakukan uji in vitro pada media selektif CMCA (Carboxyl Methyl Cellulose Agar), selanjutnya dilakukan uji in vivo pada substrat limbah kulit buah kakao. Hasil penelitian menunjukan kapang $A$. niger mampu mendegradasi selulosa secara in vitro, terbukti dari zona bening yang terbentuk pada media spesifik CMCA. Pengujian secara in vivo pada limbah kulit buah kakao menunjukan terjadi penurunan kadar $\mathrm{C} / \mathrm{N}$ rasio yang berkisar antara $18,940 \%$ 40,623\%. Kombinasi perlakuan A3B3 (jumlah inokulum $15 \mathrm{~mL}$, waktu inkubasi 28 hari) menghasilkan kadar $\mathrm{C} / \mathrm{N}$ rasio terendah yaitu sebesar $18.940 \%$.
\end{abstract}

Kata Kunci:limbah kulit buah kakao, Aspergillus niger, biodegradasi, C/N rasio

\section{ABSTRACT}

Crop waste of cacao (Theobroma cacao L.) processing waste that doesn't handle with care can polluting the environment around the farm. Rind of cacao can be used for composting, but it can be less effective because the nutrient of fresh cacao rind too complex and the ratio of $\mathrm{C} / \mathrm{N}$ too high. This research intention to knows the potential of Aspergillus niger to degrade cellulose on waste cacao rind who have high ratio of $\mathrm{C} / \mathrm{N}$, with combination inoculum concentration and incubation time. The methods of this research begin with isolation and identification of $A$. niger from litter of cacao field, then the in vitro test done by CMCA (Carboxyl Methyl Cellulose Agar) selective media, and then the cacao rind was testing by in vivo method. The results of this research shown that $A$. niger can degrade cellulose by in vitro ways, it can be seen by the clear zone that formed on CMCA selective media. The in vivo test on cacao rind shown decreasing of $\mathrm{C} / \mathrm{N}$ ratio between $18,940 \%-40,623 \%$. Combination of A3B3 treatment (15 mL inoculum concentration, 28 days incubation time) indicate the lowest $\mathrm{C} / \mathrm{N}$ ratio $18,940 \%$.

Keywords:cacao rind waste, Aspergillus niger, biodegradation, $\mathrm{C} / \mathrm{N}$ ratio 


\section{PENDAHULUAN}

Kakao (Theobroma cacao L.) merupakan salah satu jenis tanaman perkebunan yang sangat potensial dikembangkan di Indonesia. Kakao menjadi komoditas andalan Indonesia dengan jumlah produksi terbesar ketiga di dunia setelah Pantai Gading dan Ghana. Produksi rata-rata kakao Indonesia tiap tahunnya dapat mencapai 650.000 ton, bahkan pada tahun 2010 sempat menembus angka 772.800 ton (BPS, 2017).

Permasalahan yang sering dihadapi petani kakao adalah limbah yang dihasilkan dari pengolahan buah kakao. Limbah hasil panen atau pengolahan yang tidak ditangani dengan baik dapat mencemari lingkungan sekitar perkebunan. Purwaningsih dkk.(2014) mengatakan penanganan limbah yang baik dan benar, selain diharapkan mampu meningkatkan hasil produksi juga untuk menerapkan program zero waste industry.

Limbah hasil panen atau pengolahan sebagian besar adalah berupa kulit buah. Menurut Daud et al.(2013) buah kakao mengandung $74 \%$ kulit buah, $24 \%$ biji dan sekitar $2 \%$ plasenta. Kandungan nutrisi dalam kulit buah kakao memiliki kualitas yang lebih baik dibandingkan dengan limbah perkebunan lainnya seperti pucuk tebu, tetes dan kulit kopi (Puastuti dan Yulistiani, 2011). Pemanfaatan limbah kulit buah kakao yang paling sederhana dan sering kita jumpai adalah sebagai pupuk alami penyubur tanaman atau kompos.

Pengomposan adalah proses penguraian bahan organik secara biologis melalui bantuan mikroorganisme yang memanfaatkan bahan organik tersebut sebagai sumber energi. Yunindanova (2009) mengatakan bahwa kompos merupakan hasil penguraian atau dekomposisi bahan-bahan organik dari tumbuhan, hewan maupun limbah organik lainnya. Laju pengomposan suatu bahan organik sangat dipengaruhi oleh $\mathrm{C} / \mathrm{N}$ rasio, jika $\mathrm{C} / \mathrm{N}$ rasio suatu bahan tinggi maka proses dekomposisi akan berlangsung lambat, sebaliknya jika $\mathrm{C} / \mathrm{N}$ rasio rendah maka proses dekomposisi bahan organik akan berlangsung dengan cepat (Vukobratovic et al., 2008). Limbah bahan organik yang berasal dari tumbuhan biasanya memiliki $\mathrm{C} / \mathrm{N}$ rasio yang cukup tinggi karena bahan-bahan tersebut tersusun dari komponen selulosa yang memerlukan perlakuan khusus mikroorganisme selulolitik untuk mendegradasinya (Sentana dkk.,2010).

Aspergillus niger dikenal sebagai salah satu jenis kapang selulolitik yang mampu menghasilkan enzim selulase dengan baik. Enzim yang dihasilkan dari kapang ini tergolong enzim ekstra seluler yang berfungsi memecah molekul-molekul komplek menjadi molekul yang lebih sederhana. Berdasarkan latar belakang tersebut, perlu dilakukan penelitian mengenai pemanfaatan limbah kulit buah kakao sebagai kompos dengan memanfaatkan kapang-kapang selulolitik terutama jenis A. niger yang telah diketahui potensinya.

\section{METODE PENELITIAN}

\section{Tempat dan Waktu Penelitian}

Pengambilan sampel serasah untuk isolasi kapang Aspergillus niger dilakukan di salah satu lahan perkebunan kakao yang berada di Desa Tuwed, Kecamatan Melaya, Kabupaten Jembrana. Isolasi dan uji potensi selulolitik kapang A. niger dalam mendegradasi limbah kulit buah kakao baik secara in vitro maupun in vivo dilakukan di Laboratorium Mikrobiologi, Program Studi Biologi, Fakultas MIPA, Universitas Udayana. Analisis penentuan $\mathrm{C} / \mathrm{N}$ rasio sampel bahan dilakukan di Laboratorium Konsentrasi Tanah dan Lingkungan, Fakultas Pertanian, Universitas Udayana.

\section{Isolasi dan Identifikasi Kapang Aspergillus niger \\ Sampel serasah yang telah} diperoleh diisolasi menggunakan metode 
pengenceran (platting method). Serasah dihancurkan menjadi kecil-kecil dan ditimbang sebanyak $10 \mathrm{~g}$, kemudian dimasukkan kedalam $90 \mathrm{~mL}$ air steril lalu dihomogenkan untuk memperoleh faktor pengenceran $10^{-1}$. Disiapkan empat buah tabung reaksi yang masing-masing berisi 9 $\mathrm{mL}$ air steril, pengenceran dilanjutkan dengan mengambil $1 \mathrm{~mL}$ dari faktor pengenceran $10^{-1}$ dan dimasukkan kedalam $9 \mathrm{~mL}$ air steril pada tabung reaksi lalu dihomogenkan dengan vortex sehingga diperoleh faktor pengenceran $10^{-2}$. Demikian seterusnya dilakukan hingga mencapai faktor pengenceran $10^{-5}$. Sebanyak $1 \mathrm{~mL}$ suspensi diambil pada masing-masing faktor pengenceran $10^{-2}$ sampai $10^{-5}$ untuk ditanam pada media PDA (potato dextrose agar)+kloramfenikol dengan metode pour plate. Semua proses dikerjakan secara aseptik dekat api Bunsen untuk menghindari kontaminasi, kemudian dilakukan inkubasi pada suhu $28^{\circ} \mathrm{C}$ selama tiga hari (Nester et al., 2007). Koloni kapang diidentifikasi secara makroskopis dan mikroskopis dengan panduan buku Pitt dan Hocking (2000).

\section{Uji Potensi Selulolitik Kapang Aspergillus niger secara in vitro}

Biakan murni diambil sebanyak 1 cork borer ukuran 0,5 x 0,5 cm dan diinokulasikan pada media CMCA (Carboxyl Methyl Cellulose Agar) dalam cawan Petri. Setelah diinokulasi cawan Petri diinkubasi pada suhu $28^{\circ} \mathrm{C}$ selama tiga hari. Setelah koloni kapang tumbuh dilakukan proses pewarnaan untuk melihat kemampuan selulolitik kapang. Pewarnaan dilakukan dengan merendam cawan Petri yang telah ditumbuhi koloni kapang menggunakan larutan Congo red 1\% sebanyak $10 \mathrm{~mL}$ selama 30 menit. Selanjutnya cawan Petri dibilas dengan air garam hingga kepekatan warna Congo red berkurang pada media. Kemampuan kapang dalam mendegradasi selulosa ditandai dengan terbentuknya zona bening (clear zone) pada media disekitar koloni (Nugraha, 2012).

\section{Penyiapan Kultur Kapang Aspergillus niger dan Substrat Limbah Kulit Buah Kakao}

Biakan murni kapang Aspergillus niger yang sudah diketahui potensinya dalam mendegradasi selulosa diperbanyak sesuai dengan kebutuhan pada media PDA (Potato Dextrose Agar). Isolat kapang yang telah tumbuh pada cawan Petri ditambahkan air steril kemudian digerus menggunakan cork borer sehingga spora kapang akan tersuspensi pada air steril. Kemudian suspensi spora kapang dimasukan ke dalam empat buah tabung Erlenmeyer yang berisi masing-masing 25 $\mathrm{mL}$ air steril, selanjutnya suspensi dihomogenkan (Happy et al., 2014).

Limbah kulit buah kakao yang dipilih sebagai substrat adalah limbah yang masih segar atau belum mengalami proses pembusukan, sebanyak kurang lebih $7 \mathrm{~kg}$ limbah diambil, dicuci bersih lalu dihancurkan menjadi bagian yang lebih kecil dengan cara digiling. Setelah rata, bahan substrat dimasukkan dalam wadah plastik tahan panas masing-masing sebanyak $200 \mathrm{~g}$ dibuat sesuai dengan jumlah perlakuan. Mulut plastik diberi penutup berukuran kecil hingga dipastikan tidak ada lubang atau celah. Substrat yang telah selesai dibuat disterilisasi untuk menghindari kontaminasi oleh mikroorganisme yang tidak diinginkan (Nugraha, 2012).

\section{Uji Potensi Selulolitik Kapang Aspergillus niger pada Limbah Kulit Buah Kakao secara in vivo}

Substrat yang telah disterilisasi kemudian disuspensikan dengan biakan murni A. niger yang telah dibuat. Suspensi biakan kapang dimasukan dalam substrat yang telah dibuat lalu dihomogenkan dengan cara diaduk. Substrat ditutup kembali dan diberi label sesuai dengan perlakuan jumlah inokulum. Diinkubasi dalam suhu $28^{\circ} \mathrm{C}$ dengan kombinasi lama waktu yang telah ditentukan. Semua proses pengerjaan dilakukan secara aseptis. 
Analisa yang dilakukan meliputi kadar Corganik, kadar $\mathrm{N}$-total dan $\mathrm{C} / \mathrm{N}$ rasio.

Pengujian potensi selulolitik kapang A. niger pada substrat limbah kulit buah kakao dilakukan dengan menggunakan Rancangan Acak Lengkap (RAL) pola factorial $2 \times 3$. Faktor pertama adalah jumlah inokulum yang terdiri dari tiga taraf yaitu $5 \mathrm{~mL}, 10 \mathrm{~mL}$ dan $15 \mathrm{~mL}$. Faktor kedua adalah waktu inkubasi yang terdiri dari tiga taraf juga yaitu 14 hari, 21 hari dan 28 hari. Perlakuan diulang sebanyak tiga kali dan dibuat kontrol tanpa perlakuan untuk melihat perbandingannya. Data yang diperoleh dianalisis statistik menggunakan program SPSS 22 dengan analysis of varians (ANOVA). Apabila diperoleh data yang berbeda nyata, maka analisis dilanjutkan dengan menggunakan uji Duncanpada taraf 5\% untuk mengetahui derajat beda pada masing-masing faktor perlakuan.
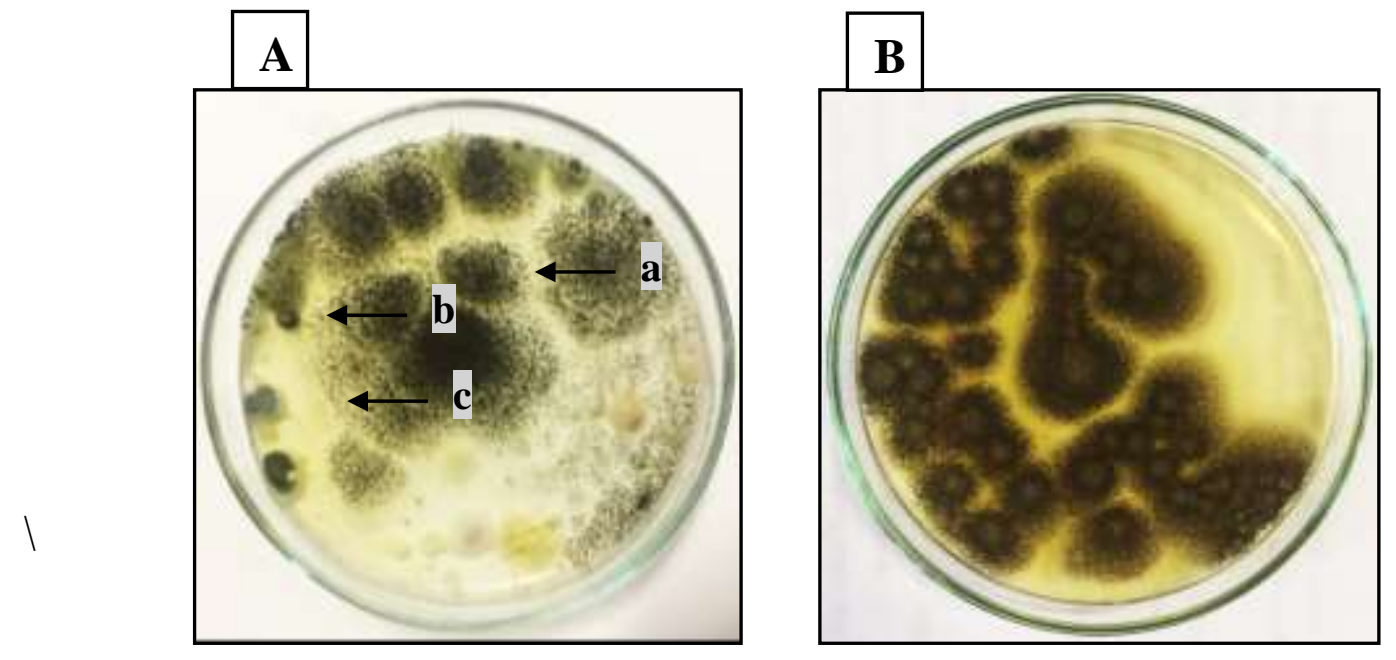

Gambar 1.Isolasi kapang Aspergillus niger pada serasah perkebunan kakao Keterangan : A. Koloni kapang yang tumbuh pada media PDA setelah masa inkubasi empat hari( $\mathrm{a}=$ A.niger $; \mathrm{b}=$ spesies 1 ; dan $\mathrm{c}=$ spesies 2$)$. B. Koloni kapang A. niger hasil reisolasi pada media PDA masa inkubasi lima hari

Kapang yang diperoleh kemudian direisolasi agar mendapatkan koloni murni. Hasil reisolasi kapang yang diduga $A$. niger pada media PDA ditunjukan pada Gambar 1.B. Berdasarkan hasil pengamatan secara makroskopis koloni kapang yang

\section{HASIL DAN PEMBAHASAN}

\section{Isolasi dan Identifikasi Kapang Aspergillus niger pada Serasah Perkebunan Kakao}

Hasil isolasi kapang pada serasah perkebunan kakao di Desa Tuwed, Kecamatan Melaya, Kabupaten Jembrana, Bali, ditemukan tiga jenis kapang yang tumbuh pada media PDA (Potato Dextrose Agar) setelah masa inkubasi 4 hari. Satu jenis kapang diduga sebagai $A$. niger dan dua jenis lainnya tidak teridentifikasi (spesies 1 dan spesies 2). Berdasarkan luas area koloni, kapang yang diduga $A$. niger tumbuh paling mendominasi pada cawan Petri. Hasil isolasi kapang pada serasah perkebunan kakao dapat dilihat pada Gambar 1.A. 
cawan Petri, diameter koloni bervariasi antara $1-3 \mathrm{~cm}$ pada masa inkubasi lima hari di media PDA (Gambar 1.B).

Hasil pengamatan secara mikroskopis menggunakan mikroskop cahaya dengan pembesaran 100x akan terlihat seperti Gambar 2.A, tampak bagian-bagian kapang $A$. niger seperti konidium, konidiofor dan foot cell yang merupakan bentuk modifikasi dari hifa $A$. niger. Pengamatan dengan pembesaran 400x (Gambar 2.B) terlihat jelas bagiabagian kapang seperti vesikula, konidiofor dan kumpulan konidia berbentuk bulat kecil-kecil berwarna coklat kehitaman menyerupai mutiara. Hasil pengamatan $A$. niger secara makroskopis dan mikroskopis dapat dilihat pada Tabel 1.

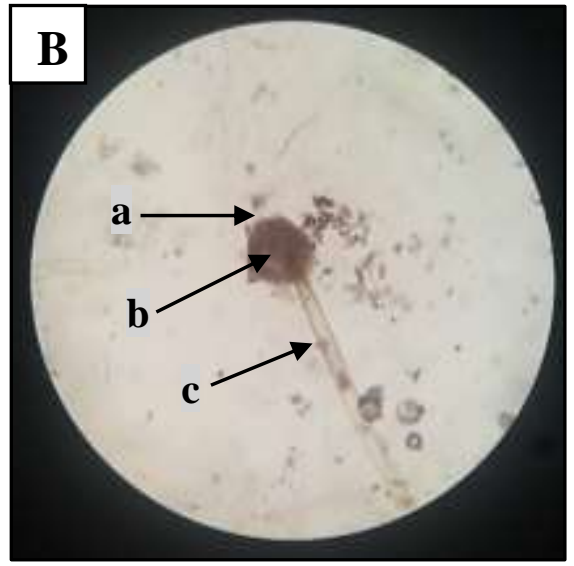

Gambar 2. Hasil pengamatan mikroskopis kapang Aspergillus niger

Keterangan : A. Mikroskopis A. niger pembesaran 100x pada mikroskop cahaya (a=konidium: $\mathrm{b}=$ konidiofor: $\mathrm{c}=$ foot cell) $\mathrm{B}$. Mikroskopis A. niger pembesaran 400x dibawah mikroskop cahaya ( $\mathrm{a}=$ konidia; $\mathrm{b}=\mathrm{vesikel;} \mathrm{c}=$ konidiofor)

Tabel 1.Hasil pengamatan makroskopik dan mikroskopik A. niger pada medium PDA

\begin{tabular}{ll}
\hline Karakter Morfologi & \multicolumn{1}{c}{ Keterangan } \\
\hline Makroskopik & \\
\hline Warna koloni & Hitam/Coklat kehitaman \\
Warna sebalik koloni & Putih kekuningan \\
Tekstur koloni & Bergranul \\
\hline Mikroskopik & \\
Foot cell & Ada \\
Konidiofor & Ada \\
Konidium & Ada \\
Konidia & Bulat \\
Vesikel & Bulat \\
\hline
\end{tabular}

Menurut Noverita (2009) secara makroskopis koloni kapang A. niger berwarna putih ketika masih muda dan berubah menjadi hitam atau coklat 
kehitaman ketika sudah tua, permukaan bawah koloni berwarna putih atau putih kekuningan yang kemudian berubah menjadi coklat gelap setelah membentuk konidia.Secara mikroskopis kapang $A$. niger memiliki karakteristik hifa yang berseptap, konidiofor muncul dari foot cell (sel kaki) yaitu hifa-hifa yang membengkok dan menebal, vesikel bulat hingga semi bulat dengan diameter 10-100 $\mu \mathrm{m}$, sterigma biasanya sederhana, berwarna atau tidak berwarna, konidia menyerupai untaian mutiara dengan diameter 1,5-2,4 $\mu \mathrm{m}$ (Hayani dan Erina, 2017).

Istiana (2007) menambahkan secara mikroskopis kapang A. niger memiliki bagian-agian antara lain yaitu foot cell, konidiofor, vesikel, sterigma dan konidia, foot cell merupakan struktur modifikasi hifa-hifa yang menempel pada medium tempat munculnya konidiofor. Menurut Gandjar dkk (2011) A. niger memiliki struktur konidiofor yang panjang, berdinding halus, hialin (tidak berwarna) atau berwarna coklat kekuningan dengan panjang dapat mencapai $10 \mu \mathrm{m}$.

\section{Kemampuan Kapang Aspergillus niger dalam Mendegradasi Selulosa Secara in vitro \\ Hasil uji kemampuan selulolitik kapang A. niger yang dilakukan menunjukan hasil yang cukup baik. Isolat secara kualitatif mampu mendegradasi selulosa dengan adanya pembentukan zona bening pada media Carboxyl Metyl CellulosaAgar (CMCA) disekitar area tumbuh koloni, Hasil uji kemampuan selulolitik kapang A. niger dapat dilihat pada Gambar 3.}

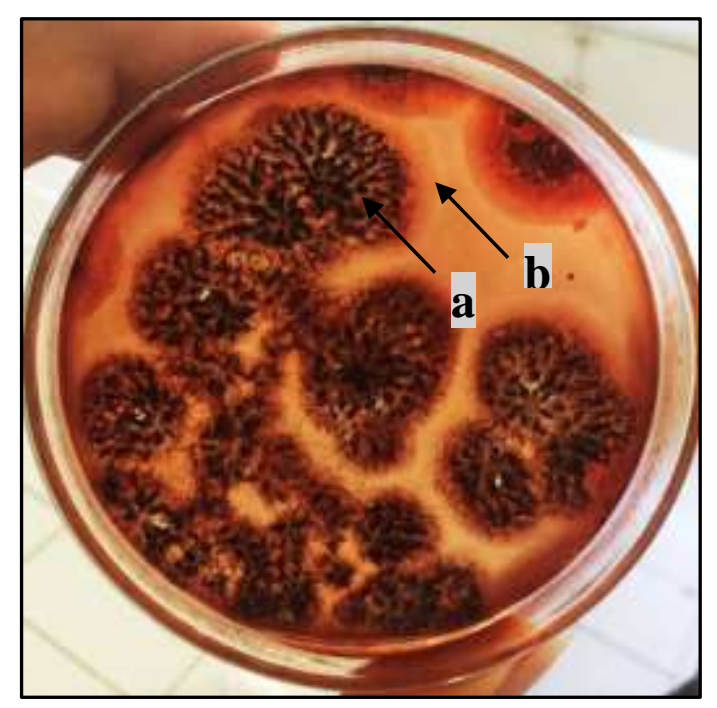

Gambar 3.Zona bening yang terbentuk oleh kapang A. niger pada media CMCA masa inkubasi lima hari.

Keterangan : a. koloni kapang Aspergillus niger ; b. zona bening

Pengujian adanya aktivitas selulolitik ditunjukan dengan terbentuknya zona bening pada media CMCA setelah diberi pewarna Congo red. Menurut Roza (2013), uji kualitatif aktivitas kapang selulolitik dapat dilakukan dengan mengukur zona bening yang terbentuk disekitar koloni. Azizah dkk (2014) menambahkan pembentukan zona bening menunjukan bahwa selulosa yang terdapat dalam media terhidrolisis menjadi senyawa yang lebih sederhana oleh adanya aktivitas enzim selulase.

Menurut Djarwanto dkk (2018) kemampuan kapang $A$. niger merombak selulosa mulai muncul pada hari ketiga dan 
maksimal pada hari ke 12 masa inkubasi. Indikasi awal untuk mengetahui kemampuan kapang dalam mendekomposisi selulosa adalah terbentuknya zona bening, semakin luas zona bening yang terbentuk secara kualitatif maka semakin besar aktivitas selulolitik yang dihasilkan (Gohel et al., 2014).

Penggunaan indikator Congo red adalah untuk melihat adanya zona bening, karena sifat zat ini akan berikatan kuat dengan komponen selulosa yaitu $\beta$ glukosidik dalam media CMCA, sehingga akan mewarnai media yang masih mengandung selulosa, dan bagian media yang tidak mengandung selulosa tidak akan terwarnai (Narashima, 2005). Pencucian dengan $\mathrm{NaCl} 1 \mathrm{M}$ dilakukan bertujuan untuk memperjelas zona bening yang terbentuk.

Aktivitas selulolitik kapang A. niger merupakan proses hidrolisis selulosa oleh bantuan enzim selulase yang dihasilkan selama proses pertumbuhan. Selulase merupakan enzim kompleks yang tersusun dari endo- $\beta$-1,4-glukanase, ekso- $\beta$-1,4glukanase dan $\beta$-glukosidase yang memiliki fungsi masing-masing didalam memecah selulosa (Chimentao et al., 2014). Endo- $\beta$-1,4-glukanase berfungsi untuk menghidrolisis polimer selulosa secara acak menjadi selodextrin, glukosa dan selobiosa. Ekso- $\beta$-1,4-glukanase berfungsi untuk menghidrolisis unit-unit selobiosa pada bagian ujung menjadi selobiosa disakarida. Sedangkan yang terakhir $\beta$ glukosidase berfungsi untuk menghidrolisis unit-unit selobiosa menjadi glukosa (Anindyawati, 2010).

Kemampuan Kapang Aspergillus niger dalam Mendegradasi Selulosa pada Limbah Kulit Buah Kakao secara in vivo

Kemampuan kapang A. niger dalam mendegradasi selulosa dapat dilihat dari penurunan rasio karbon (C) terhadap nitrogen $(\mathrm{N})$ pada limbah kulit buah kakao atau biasa disebut $\mathrm{C} / \mathrm{N}$ rasio. Selulosa merupakan salah satu komponen organik utama yang menentukan ketersediaan karbon, semakin tinggi kandungan selulosa semakin tinggi pula kandungan karbon organik pada suatu bahan (Nurida dkk., 2012).

Analisis limbah kulit buah kakao tanpa perlakuan dilakukan untuk mengetahui kandungan awal bahan organik yang dapat dijadikan sebagai pembanding atau kontrol apakah terjadi penurunan $\mathrm{C} / \mathrm{N}$ rasio atau tidak setelah diberikan perlakuan pada preparasi sampel yang sama. Hasil analisis $\mathrm{C} / \mathrm{N}$ rasio limbah kulit buah kakao sebelum atau tanpa perlakuan disajikan pada Tabel 2.

Tabel 2. Hasil analisis rasio C/N limbah kulit buah kakao tanpa perlakuan

\begin{tabular}{lc}
\hline Parameter & Jumlah (\%) \\
\hline C-Organik & 48,091 \\
N-Total & 0,831 \\
Rasio C/N & 57,893 \\
\hline
\end{tabular}

Hasil analisis menunjukan bahwa kandungan C-organik untuk limbah kulit buah kakao adalah sebesar 48,091\% dan Ntotal sebesar $0,831 \%$ sehingga didapat rasio $\mathrm{C} / \mathrm{N}$ adalah sebesar $57,893 \%$. C/N rasio yang didapat tergolong masih sangat tinggi sehingga setelah diberikan perlakuan diharapkan terjadi penurunan $\mathrm{C} / \mathrm{N}$ rasio menjadi sama dengan $\mathrm{C} / \mathrm{N}$ rasio tanah yaitu berkisar antara 10-20 atau sesuai dengan standar mutu pupuk organik yaitu antara 15-25 (Eviati dan Sulaiman, 2009). 


\section{$\mathrm{C} / \mathrm{N}$ rasio}

Berdasarkan analisis $\mathrm{C} / \mathrm{N}$ rasio yang dilakukan di Laboratorium Tanah Fakultas Pertanian Universitas Udayana, diperoleh rata-rata kadar $\mathrm{C} / \mathrm{N}$ rasio limbah kulit buah kakao adalah seperti Tabel 3.

Tabel 3. Hasil analisis kadar C/N rasio limbah kulit buah kakao.

\begin{tabular}{cc}
\hline Perlakuan & $\begin{array}{c}\text { Rata-rata } \\
\text { C/N Rasio (\%) }\end{array}$ \\
\hline A1B1 & 40,623 \\
A1B2 & 30,039 \\
A1B3 & 21,711 \\
A2B1 & 36,464 \\
A2B2 & 26,680 \\
A2B3 & 19,708 \\
A3B1 & 33,761 \\
A3B2 & 22,086 \\
A3B3 & 18,940 \\
\hline
\end{tabular}

Keterangan: A1B1 : Jumlah inokulum $5 \mathrm{~mL}$, waktu inkubasi 14 hari

A1B2 : Jumlah inokulum $5 \mathrm{~mL}$, waktu inkubasi 21 hari

A1B3 : Jumlah inokulum $5 \mathrm{~mL}$, waktu inkubasi 28 hari

A2B1 : Jumlah inokulum $10 \mathrm{~mL}$, waktu inkubasi 14 hari

A2B2 : Jumlah inokulum $10 \mathrm{~mL}$, waktu inkubasi 21 hari

A2B3 : Jumlah inokulum $10 \mathrm{~mL}$, waktu inkubasi 28 hari

A3B 1 : Jumlah inokulum $15 \mathrm{~mL}$, waktu inkubasi 14 hari

A3B2: Jumlah inokulum $15 \mathrm{~mL}$, waktu inkubasi 21 hari

A3B3 : Jumlah inokulum $15 \mathrm{~mL}$, waktu inkubasi 28 hari

Rata-rata kadar $\mathrm{C} / \mathrm{N}$ rasio limbah kulit buah kakao berkisar antara 18,940\%40,623\%. Hasil penurunan tertinggi diperoleh pada kombinasi perlakuan A3B3 (jumlah inokulum $15 \mathrm{~mL}$, waktu inkubasi 28 minggu) dan penurunan terendah diperoleh pada kombinasi perlakuan A1B1 (jumlah inokulum $5 \mathrm{ml}$, waktu inkubasi 14 hari). Secara keseluruhan, jika dibandingkan dengan kontrol, pemberian kombinasi perlakuan terbukti dapat menurunkan kadar $\mathrm{C} / \mathrm{N}$ rasio limbah kulit buah kakao.
Berdasarkan hasil analisis statistik terhadap $\mathrm{C} / \mathrm{N}$ rasio menunjukan faktor perlakuan jumlah inokulum berpengaruh sangat nyata terhadap $\mathrm{C} / \mathrm{N}$ rasio $(\mathrm{P}=0,000)$, begitu juga dengan faktor perlakuan waktu inkubasi memberikan pengaruh yang sangat nyata terhadap $\mathrm{C} / \mathrm{N}$ rasio $(\mathrm{P}=0,000)$. Sedangkan untuk interaksi antara faktor perlakuan jumlah inokulum dan faktor perlakuan waktu inkubasi tidak berpengaruh nyata $(\mathrm{P}=0,263)$.

Hasil uji Duncan menunjukan jumlah inokulum kapang $A$. niger berpengaruh terhadap $\mathrm{C} / \mathrm{N}$ rasio limbah 
kulit buah kakao, jumlah inokulum $15 \mathrm{~mL}$ menunjukan hasil kadar $\mathrm{C} / \mathrm{N}$ rasio paling rendah dibandingkan dengan jumlah inokulum $10 \mathrm{~mL}$ dan $5 \mathrm{~mL}$, hal ini menunjukan penambahan jumlah inokulum $15 \mathrm{~mL}$ lebih efektif menurunkan kadar $\mathrm{C} / \mathrm{N}$ rasio. Suriadikarta dan Abdurahman (2008) mengatakan semakin banyak jumlah inokulum maka proses degradasi selulosa akan semakin meningkat. Proses metabolisme oleh kapang A.niger akan semakin cepat dan semakin banyak karbon yang dimanfaatkan untuk pembentukan dan perkembangan sel (Rahmah dkk., 2014).

Tabel 4 Uji Duncan kadar C/N rasio limbah kulit buah kakao (jumlah inokulum)

\begin{tabular}{cc}
\hline Jumlah Inokulum & C/N Rasio \\
\hline A1 & $30,791 \pm 8,503 \mathrm{a}$ \\
A2 & $27,617 \pm 7,493 \mathrm{~b}$ \\
A3 & $24,929 \pm 6,888 \mathrm{c}$
\end{tabular}

Keterangan : Angka yang diikuti oleh notasi huruf kecil yang berbeda pada kolom menunjukan nilai berbeda nyata $(\mathrm{P} \leq 0,05)$ pada taraf $\alpha 5 \%$.

A1 : $5 \mathrm{~mL}$

A2 : $10 \mathrm{~mL}$

A3 : $15 \mathrm{~mL}$

Waktu inkubasi berpengaruh terhadap $\mathrm{C} / \mathrm{N}$ rasio limbah kulit buah kakao, kadar $\mathrm{C} / \mathrm{N}$ rasio paling rendah dihasilkan pada waktu inkubasi 28 hari. Perlakuan dengan waktu inkubasi 14 hari dapat dikatakan kurang efektif karena berkaitan dengan kurva pertumbuhan kapang. Kapang A.niger mulai dapat melakuan perombakan selulosa setelah hari ketiga inokulasi (Anita, 2013). Menurut Indriyani (2004), proses degradasi juga sangat dipengaruhi oleh ukuran bahan organik. Preparasi sampel limbah kulit buah kakao dengan cara mencacah dapat mempercepat proses degradasi karena semakin luas permukaan yang tersedia bagi kapang A.niger untuk tumbuh.

Tabel 5 Uji Duncan kadar C/N rasio limbah kulit buah kakao (waktu inkubasi)

\begin{tabular}{cc}
\hline Waktu Inkubasi & C/N Rasio \\
\hline B1 & $36,949 \pm 3,480 \mathrm{a}$ \\
B2 & $26,268 \pm 4,127 \mathrm{~b}$ \\
B3 & $20,119 \pm 1,720 \mathrm{c}$
\end{tabular}

Keterangan : Angka yang diikuti oleh notasi huruf kecil yang berbeda pada kolom menunjukan nilai berbeda nyata $(\mathrm{P} \leq 0,05)$ pada taraf $\alpha 5 \%$.

B1 : 14 hari

B2 : 21 hari

B3 : 28 hari

Berdasarkan hasil kadar $\mathrm{C} / \mathrm{N}$ rasio yang diperoleh, hanya kombinasi perlakuan A2B3 (jumlah inokulum $10 \mathrm{~mL}$, waktu inkubasi 28 hari) dan A3B3 (jumlah inokulum 15 $\mathrm{mL}$, waktu inkubasi 28 hari) saja yang memenuhi standar mutu kompos menurut SNI 19-7030-2004 yaitu minimum 10\% dan maksimum $20 \%$. Kombinasi perlakuan A2B3 menghasilkan kadar $\mathrm{C} / \mathrm{N}$ rasio sebesar 19,708\%, sedangkan A3B3 
menghasilkan kadar $\mathrm{C} / \mathrm{N}$ rasio sebesar $18,940 \%$.

\section{SIMPULAN}

Kapang Aspergillus niger yang diisolasi dari serasah perkebunan kakao mampu mendegradasi selulosa secara in vitro, terbukti dari zona bening yang terbentuk pada media spesifik CMCA. Kombinasi jumlah inokulum dan waktu inkubasi berpengaruh terhadap proses biodegradasi limbah kulit buah kakao, terjadi penurunan kadar $\mathrm{C} / \mathrm{N}$ rasio yang berkisar antara 18,940\%-40,623\%. Kombinasi perlakuan A3B3 (jumlah inokulum $15 \mathrm{ml}$, waktu inkubasi 28 hari) mampu menghasilkan kadar $\mathrm{C} / \mathrm{N}$ rasio terendah sebesar $18.940 \%$.

\section{UCAPAN TERIMA KASIH}

Terima kasih yang sebesarbesarnya penulis ucapkan kepada Bapak Dr. Drs. Ida Bagus Gede Darmayasa M.Si dan I Ketut Muksin S.Si.,M.Si selaku pembimbing yang telah memberikan bimbingan, masukan, ide-ide serta semngat untuk menyelesaikan jurnal ini.

\section{DAFTAR PUSTAKA}

Anindyawati, T. 2009. Prospek Enzim dan Limbah Lignoselulosa untuk Produksi Bioetanol. B.S. 44(1):4956.

Anita, S. S. N. I. T. 2013. Efektivitas campuranEnzim Selulase dari Aspergillus niger dan Trichoderma reesei dalam Menghidrolisis Substrat Sabut Kelapa. Jurnal Kimia Khatulistiwa. 2(1):46-51

Azizah, D. N., Kumolowati, E. dan Faramayuda, F. 2014. Penetapan Kadar Flavonoid Metode $\mathrm{AlCl}_{3}$ pada Ekstrak Metanol Kulit Buah Kakao (Theobroma cacao L.). Kartika Jurnal Ilmiah Farmasi. 2(2): 45-49.

Badan Pusat Statistik (BPS). 2017. Statistik Indonesia Tahun 2017. Badan Pusat Statistik. Jakarta Pusat.
Chimentao, R. J., E. Lorente, F. G. Guirado, F. Medina and F. Lopez. 2014. Hydrolisys of Dilute AcidPretreated Cellulose Under Mild Hydrothermal Conditions. Carbohydrate Polymers. 111:116124

Daud, G., A. S. M. Kassim, A. M. Aripin, H. Awang and M. Z. M. Hatta. 2013. Chemical Composition and Morphological of Cocoa Pod Husks and Cassava Peels for Pulp and Paper Production. Australian Journal of Basic Applied Science. 7(9):406-411.

Djarwanto., S. Suprapti dan F. J. Hutapea. 2018. Kemampuan Sepuluh Strain Jamur Melapukan Empat Jenis Kayu Asal Manokwari. Jurnal Penelitian Hasil Hutan. 36(2):129138.

Eviati dan Sulaeman. 2009. Petunjuk Teknis Analisis Kimia Tanah, Tanaman, Air dan Pupuk Edisi ke2. Balai Penelitian Tanah. Bogor.

Gandjar, I., W. Sjamsuridjal dan A. Detrasi. 2011. Mikologi : Dasar dan Terapan. Yayasan Obor Indonesia. Jakarta.

Gohel, H. R., C. N. Contractor, S. K. Ghosh and V. J. Braganza. 2014. A Comparative Study of Various Staining Techniques for Determinating of Extra Cellular Cellulase Activity on Carboxy Methyl Cellulase (CMC) Agar Plates. Int J Curr Microbiol. 3:261266.

Happy, Z. M., Zul, D. dan Febriarti B.L. 2014. Aplikasi Mikroba Lignoselulolitik Indigenus Asal Tanah Gambut Riau dalam Pembuatan Kompos dari Campuran Tandan Kosong dan Limbah Cair Pabrik Kelapa Sawit. JOM FMIPA. 1(2):213-223.

Hayani, N dan D. Erina. 2017. Isolasi Aspergillus sp. pada Paru-paru Ayam Kampung (Gallus domesticus). Jimvet. 1(4):637-643. 
Indriani, Y. H. 2004. Membuat Kompos Secara Kilat. Penebar Swadaya. Jakarta.

Istiana. 2007. Aplikasi Pupuk Nitrogen dan Pengaruhnya pada Tanaman Tembakau Madura. Buletin Teknik Pertanian. 12(2).

Narashima, G. 2005. Nutrient Effect on Productions of Cellulolytic Enzymes by Aspergillus niger. Journal Biotechnol 5:472-476.

Nester, E. W., Aderson, D. G., Robert C. E. and Nester, M. 2007. Microbiology. Fifth Edition. Published by McGraw-Hill. America, New York.

Noverita, A. 2009. Isolasi dan Uji Aktivitas Antibakteri Jamur Endofit dari Daun dan Rimpang Zingiber ottensii Val. Jurnal Farmasi Indonesia. 4(4):171-176.

Nugraha, A. W. 2012. Isolasi dan Biodegradasi Limbah Daduk oleh Kapang Selulolitik dari Perkebunan Tebu. Skripsi. Unair : Surabaya.

Nurida, N. L., A. Rachman dan Sutono. 2012. Potensi Pembenahan Tanah Biochar dalam Pemulihan Sifat Tanah Terdegradasi dan Peningkatan Hasil Jagung pada Typic Kanhapludults Lampung. Jurnal Penelitian Ilmu-ilmu Kelaman. 12(1):69-74.

Puastuti, W dan D. Yulistiani. 2011. Ransum Berbasis Kulit Buah Kakao yang Disuplementasi Zn Organik: Respon Pertumbuhan pada Domba. JITV. 16:269-277.

Purwaningsih, A., Mudjiono, G. dan Karindah, S. 2014. Pengaruh Pengelolaan Habitat Terhadap Serangan Penggerek Buah Conopomorpha cramerella dan
Kepik Helopeltis antonii pada Kakao. JTIDP. 1(3): 149-156.

Rahmah, N. L., N. A. Setyaningtyas dan N. Hidayat. 2014. Karakteristik Kompos Berbahan Dasar Limbah Baglog Jamur Tiram (Kajian Konsentrasi EM4 dan Kotoran Kambing. Jurnal Industrial. 4(1):19.

Roza, R. M. 2013. Isolasi dan Seleksi Jamur Selulolitik dari Tanah Gambut di Perkebunan Karet Desa Rimbo Panjang Kabupaten Kampar Riau. Semirata. 1(1):263-266.

Sentana, S., Suyanto, M. A. Subarto, Suprapedi dan Sudiyana. 2010. Pengembangan dan Pengujian Inokulum untuk Pengomposan Limbah Tandan Kosong Kelapa Sawit. Jurnal Rekayasa Proses. 2(4):35-39.

Suriadikarta, D. A. dan A. Abdurahman. 2015. Pengunaan Pupuk dalam Rangka Peningkatan Produktifitas Lahan Sawah. Jurnal Penelitian dan Pengembangan Pertanian. 20(4):25-34

Vokobratovic, M., Loncaric Z. and Civic H. 2008. Composting of Wheat Straw by Using Sheep Mature and Effective Microorganisms. Agromomski Glasnik 4/2008. ISSN 0002-1954.

Yunindanova, M. B. 2009. Tingkat Kematangan Kompos Tandan Kosong Kelapa Sawit dan Penggunaan Berbagai Jenis Mulsa Terhadap Pertumbuhan dan Produksi Tanaman Tomat (Lycopersicon esculentum Mill.) dan cabai (Capsicum annuum L.). Skripsi. IPB. 